\title{
Hybrid Power Plants: Viability for Cities in Minas Gerais
}

\author{
Eduarda Moreira Nascimento ${ }^{\mathrm{a}, *}$ and Júnio Damasceno de Souza ${ }^{\mathrm{b}}$ \\ Centro Universitário de Belo Horizonte, Brazil \\ E-mail: aemn2103@gmail.com (Corresponding author),bjunio.souza@prof.unibh.br
}

\begin{abstract}
The search for sustainability permeates present-day society, seeking new ways of development that combine the economic, social, and environmental sectors. The energy segment has an important role with regard to the change of developmental models. Hybrid models have been an effective way of electricity production around the world. Brazil has availability of both sources of energy (solar and wind power). Thus, the present work aims at investigating the potential of hybrid solar-wind energy farm in the state of Minas Gerais, especially in the Jequitinhonha Valley, the state's most needed region. The analysis conducted in the project showed that the cities studied present feasibility of deployment of renewable energy generation systems, whether hybrid or by a single source. In addition, the study shows that this would be a viable alternative and those investments, currently intended for the development of nuclear power plants could be destined for this type of generation since nuclear power plant put public health at risk.
\end{abstract}

Keywords: Solar, wind, feasibility.

ENGINEERING JOURNAL Volume 21 Issue 5

Received 29 December 2016

Accepted 13 March 2017

Published 29 September 2017

Online at http://www.engj.org/

DOI:10.4186/ej.2017.21.5.37 


\section{Introduction}

The search for sustainability permeates current society, seeking new forms of development that ally the economic, social and, environmental sectors. The energy sector plays an important role in changing developmental models since conventional energy sources have major environmental impacts. Thus, the use of renewable energy sources meets this desire for sustainability.

The rapid exhaustion of conventional energy resources is a major concern and can lead to a crisis if it is not taken seriously [1]. To avoid such circumstances, researchers are forced to explore alternative sources of energy. These sources include solar, wind, biomass, and geothermal. The association of more than one renewable source of energy is also possible. Models that combine more than one source of energy are called hybrid models, such as in hybrid solar-wind generation. According to [2], hybrid models have been an effective means of producing electricity around the world.

The largest percentage of Brazilian electricity comes from hydroelectric plants (Fig. 1), and considering the Brazilian potential, the association between solar and wind models is considered relevant since it would diversify the energy matrix, reducing the risk of collapse in times of water scarcity. Brazil has availability of both energy sources (solar and wind). The Brazilian Wind Potential Atlas [3] indicates that the Brazilian wind potential is of the order of $143 \mathrm{GW}$, with the Northeast region having the most promising wind power generation, with a potential of $75 \mathrm{GW}$. In sequence are the Southeast and South regions, with potential of the order of $29.7 \mathrm{GW}$ and $22.8 \mathrm{GW}$ respectively. As in the case of wind energy, the Northeast region shows the greatest potential for solar energy generation, followed by the Midwest and Southeast regions, however the Northern region, does not offer a high potential due to its climatic characteristics, which decreases its solar potential close to the Southern region [4]. According to [5], Brazil has a high potential for solar utilization, since the values of global solar irradiation incident in any part of the country $\left(1500-2500 \mathrm{kWh} / \mathrm{m}^{2}\right)$ are higher than those of European countries such as Germany $\left(900-1250 \mathrm{kWh} / \mathrm{m}^{2}\right)$, France $\left(900-1650 \mathrm{kWh} / \mathrm{m}^{2}\right)$, and Spain $\left(1200-1850 \mathrm{kWh} / \mathrm{m}^{2}\right)$, where this type of energy is widely used and receives government incentives.

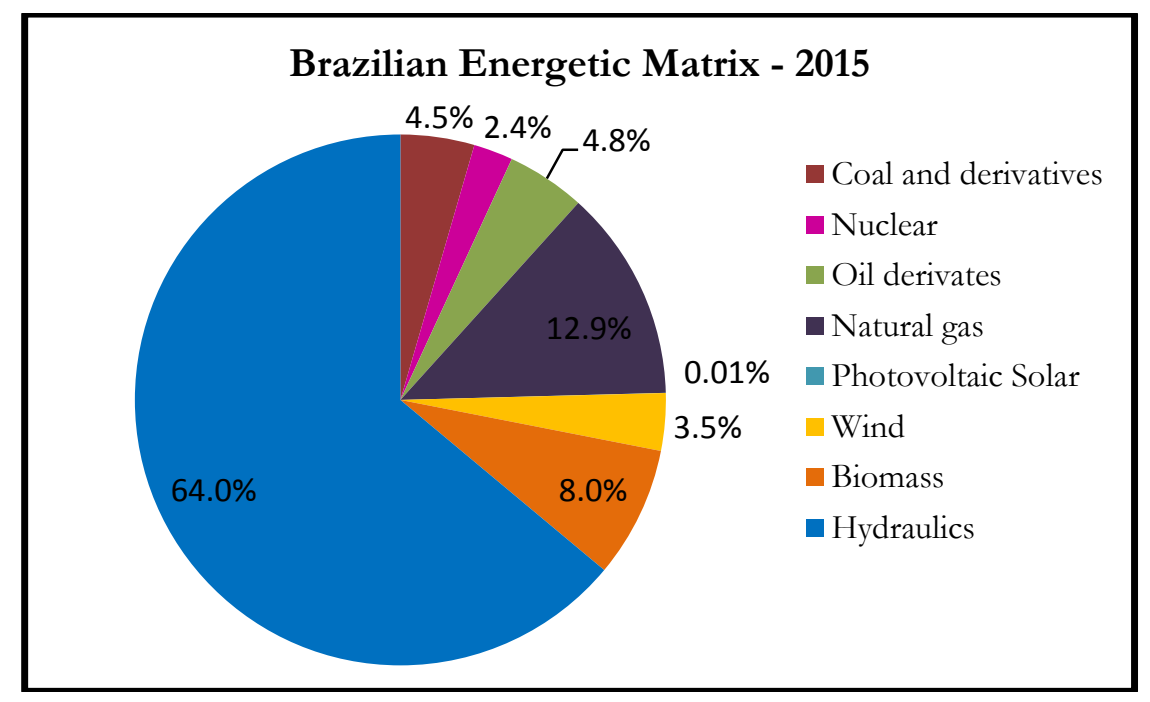

Fig. 1. Brazilian Energetic Matrix - 2015 (Source: Empresa de Pesquisa Energética - EPE, 2016.)

Brazil has a high coverage of the electricity service - 97.8\% [6]. Even so, the percentage of coverage in the rural area is much lower, which reaches $89.7 \%$. The northern region is the one with the largest energy gap, $24.1 \%$ of rural households do not have electricity, followed by rural areas in the Northeast $(7.4 \%)$ and Central West $(6.8 \%)$.

The municipalities of Jequitinhonha Valley have advanced positively in public services in the last decade. The energy sector has advanced considerably by increasing access to electricity from traditional sources to rural families in the region, reaching more than $90 \%$ of residencies. However, the cultural, land tenure, political, and environmental diversity of the Jequitinhonha Valley does not guarantee the generalized coverage of the benefits applied by the federal government. 
In this way, a better understanding of the current global and Brazilian energy scenario becomes relevant, as well as the need to develop new technologies focused on clean energy and the urgency of better management and use of natural resources.

Thus, the present work has the objective of investigating the potential of hybrid solar-wind energy exploration in Minas Gerais, especially in the Jequitinhonha Valley, which is the most economically underprivileged region of the state; as well as investigating potential hybrid generation centers and; proposing a cost estimate based on the electricity consumption of each municipality.

\subsection{Solar Energy}

\subsubsection{The solar resource}

"Solar energy is huge compared to our energy needs" [7]. This type of energy has been extensively studied from two main forms of solar energy us: photovoltaic and thermoelectric energy [8]. Solar radiation reaching the Earth's atmosphere is widespread, and the decomposition of photovoltaic interest is Horizontal Global Irradiation (GHI) representing the radiation received by a flat horizontal surface. The GHI is composed of Horizontal Diffuse Irradiation (DIF) and Direct Normal Irradiation (DNI), the first one being dispersed by elements suspended in the atmosphere and the second being a portion that reaches the surface directly. For thermoelectric use, the portion of interest is the DNI [10].

\subsubsection{Photovoltaic energy}

The electricity generated by the sun is due to the photovoltaic cells present in the panels. They convert sunlight into direct current (DC / DC). These solar cells in the photovoltaic module are made of semiconductor materials [9]. The photovoltaic system consists of four basic components: solar panels, load controllers, inverters, and battery. Solar panels are responsible for turning solar energy into electricity. The charge controllers act as valves for the system. They have the function of avoiding overcharge or excessive discharges in the battery, increasing its lifespan and performance. The inverters transform the direct current $(21 \mathrm{~V}$ or $24 \mathrm{~V})$ of the batteries into alternating current $(110 \mathrm{~V}$ or $220 \mathrm{~V})$. The battery stores the electrical energy (direct current) generated [11].

The efficiency of the system is based on the ambient temperature and the intensity of solar radiation incident on the cell. In addition, this efficiency reduces at a rate of $1 \%$ per year [10], [12]. There are several types of photovoltaic cells, some models notoriously cheaper than others, but with a much lower efficiency.

\subsubsection{Thermoelectric use}

This technology makes use of thermal energy from the sun to generate water vapor that triggers a Rankine cycle. It uses mirrored panels that reflect and concentrate solar irradiation. These panels redirect sunlight to a stationary receiver [10], [12].

\subsubsection{The Brazilian potential}

Due to its location and natural resources, Brazil has great potential for generating energy from renewable sources. As regards solar energy, the country has favorable natural characteristics. Among them are high levels of insolation and large reserves of quality quartz, which can generate an important competitive advantage for the production of silicon with a high degree of purity, cells, and solar modules [10].

The solarimetric atlases developed in the country indicate the feasibility of using solar energy in Brazilian territories [12], [3]. In general, the radiation is well distributed throughout the country, however the Northeast region presents the highest value of solar radiation. The state of Bahia, where the highest solar irradiance values were found in Brazil, has maximum irradiance values of $6.5 \mathrm{kWh} / \mathrm{m}^{2} /$ day. Due to its geographic location, the Southern region is the one with the lowest average values, the minimum in Santa Catarina $\left(4.25 \mathrm{kWh} / \mathrm{m}^{2} /\right.$ day), a region that also presents greater variability throughout the year. 


\subsubsection{Barriers in the country}

The cost of this technology continues to be a barrier to its implementation, especially considering the possibility of obtaining energy from conventional sources in a more economical way. The main costs of the system are in photovoltaic panels, line inverter and structures, and equipment. However, solar panels have demonstrated reduction of price in the international market (Fig. 2).

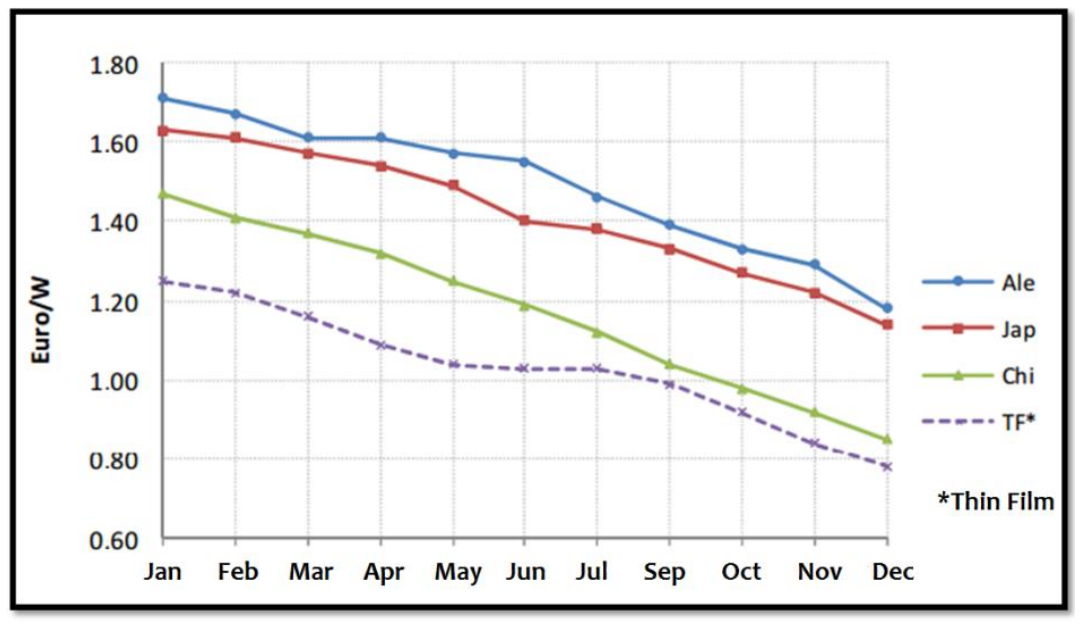

Fig. 2. Photovoltaic panels price evolution in 2011(Source: pvXchange in www.solarserver.com).

Some initiatives have been developed to soften the Brazilian barriers to the insertion of solar energy into the national energy framework. Some of these initiatives are: [13] Normative Resolution ANEEL $n^{\circ}$ 481 , of $04 / 17 / 2012$, which defines discounts of investments in the sector for small generators; The public call of ANEEL on Strategic R \& D Project no. 13/2011, which resulted in the selection of 17 photovoltaic projects to be installed in the country. Development of the Plano Brasil Maior, launched in 2011 by the federal government, which advocates improving the conditions of the country in relation to industrial competitions [14].

\subsection{Wind Energy}

"It is called wind energy the kinetic energy contained in the moving air masses, the wind" [15]. The Brazilian wind energy potential has been studied since 1970. Although slow, its track record shows progress in the industry. It is not known precisely the beginning date that man began to use the energy of the winds to carry out his activities, but probably occurred thousands of years ago in the east in machines that used aerodynamic dragging, on plates or sails, to produce work [3].

\subsubsection{Principles of technology}

The technology behind the use of winds for electric generation is as follows: wind turbines capture and transform the kinetic energy of the wind into mechanical energy that is later transformed into electricity. The rotor is connected to the main shaft, which rotates a generator to create electricity. Wind turbines are mounted on a tower to capture more energy. At 100 feet (30 meters) or more above ground, they can take advantage of the faster and less turbulent wind. Wind turbines can be used to produce electricity for a single house or building, or they can be connected to an electrical grid [15]. The electric power generated depends on the speed of the winds (V), given by Eq. (1) [3]:

$$
P(\text { Watts })=\frac{1}{2} \rho A_{r} V^{3} C_{p} \eta
$$


where: $\varrho=$ density of air in $\mathrm{kg} / \mathrm{m} 3 ; A=\pi D^{2} / 4$, where $\mathrm{A}$ is the area and $D$ is the diameter of the rotor; $C_{p}=$ Aerodynamic coefficient of rotor power e; $\eta=$ efficiency of the generator / transmission set.

The speed of the winds, when captured by wind turbines, decrease downstream and gradually increase again. After a certain distance, the wind practically returns to its initial conditions, so in practice, this distance must be respected when installing the wind turbines to ensure operating efficiency. In general, this distance is of the order of 10 times the diameter of the propeller (D) if installed downstream and 5 times D if installed beside (Fig. 3) [16].

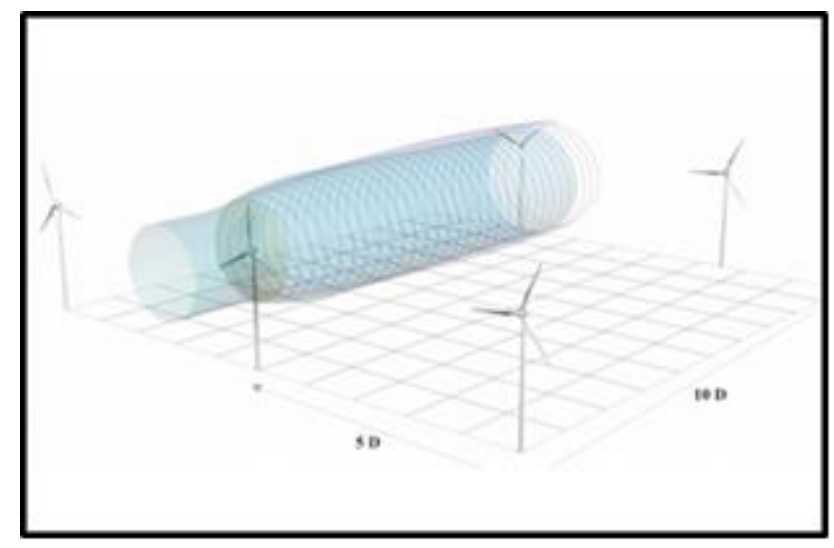

Fig. 3. Schematic drawing of the distance to be observed between wind turbines (Source: [16]).

\subsubsection{Brazilian and global scenario}

According to [17] data, installed wind power capacity reached 392,927 MW in June 2015, of which 21,678 MW were only added in the first half of the same year. The gross global energy resource is estimated at about 500,000 TWh per year, but of that number, only 53,000 TWh is considered technically feasible.

\subsubsection{Barriers in the country}

As in the case of solar energy, the cost also presents a barrier to an effective use of wind energy in the Brazilian energy framework. In addition to the price factor, other barriers faced by the sector are related to technical factors and lack of public policies to encourage the use of this resource [15].

\subsection{Hybrid Exploration}

With the scarcity of areas to be destined for electricity generation and the growing demand for electricity, the search for alternative forms of energy becomes necessary. An alternative generation model that has proven to be effective is hybrid generation. The combination of wind turbines and photovoltaic panels results in twice as much power generation in the same area, while shading losses caused by turbines are only in the order of $1 \%$ to $2 \%$ [18], [19].

Since solar radiation is not constant, just as the winds have their seasonality, the solar and wind energies, in isolated systems, do not present a reliable energy source with respect to constancy. A hybrid system of solar and wind sources coupled with energy storage cells to cover periods of time without sun or wind provides a realistic form of energy generation [2].

Battery chargers are used to charge the bank of photovoltaic panel batteries and wind input power supplies. Depending on the battery charger technology, the maximum available power can be extracted from photovoltaic panel and wind generator power sources. The battery bank is used to store surplus energy and to provide the load in case of low wind speed and / or irradiation conditions. A DC / AC Inverter is used for voltage interface to the consumer AC charging terminals of the DC battery are connected in parallel. The energy produced from each solar or wind source is transferred to the consumer load through the battery charger and DC / AC inverter, while the surplus energy, still in direct current, is used to charge the battery bank [20]. The diagram of a solar-wind hybrid system is shown below (Fig. 4): 


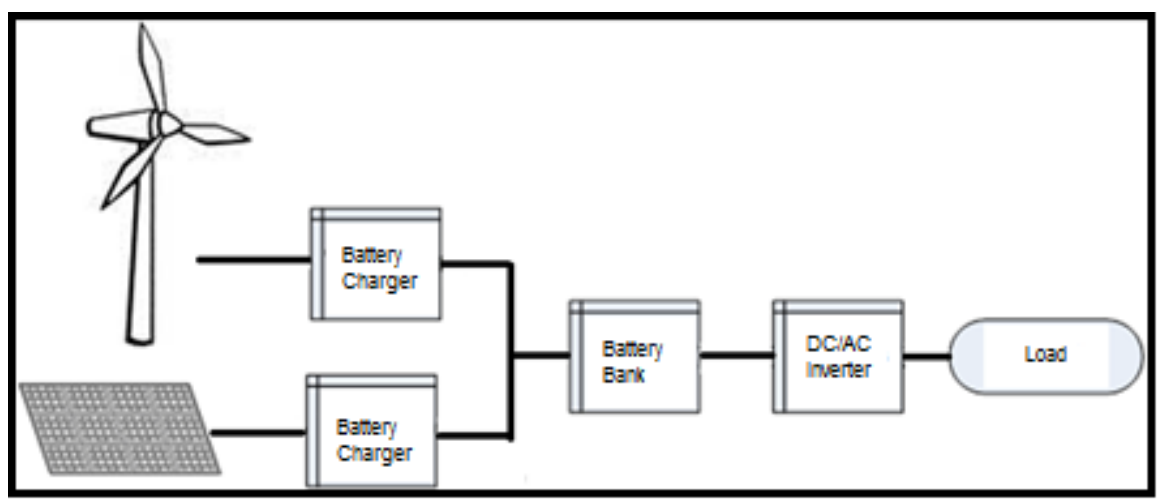

Fig. 4. Diagram of a solar-wind hybrid system.

\section{Methodology}

\subsection{Study Area}

The region of the Jequitinhonha Valley is usually remembered as the poverty place of the state of Minas Gerais. Due to cultural factors, the region's main activity is focused on agriculture. The standard of living in the region is linked to the disposition of land, the solid roof of a masonry house and, mainly, access to the water, the full batch of groceries, the farinheira and the mill that grind during the dry season to guarantee food in quantity and quality to meet the needs of the families [21]. This reality exempts the residents to look for different forms of development. The region, by its conditions, receives several income transfer programs; such as Bolsa Familia, coordinated by the Ministry of Social Development, to the extent that local income is $60 \%$ generated by such programs (Fig. 5).

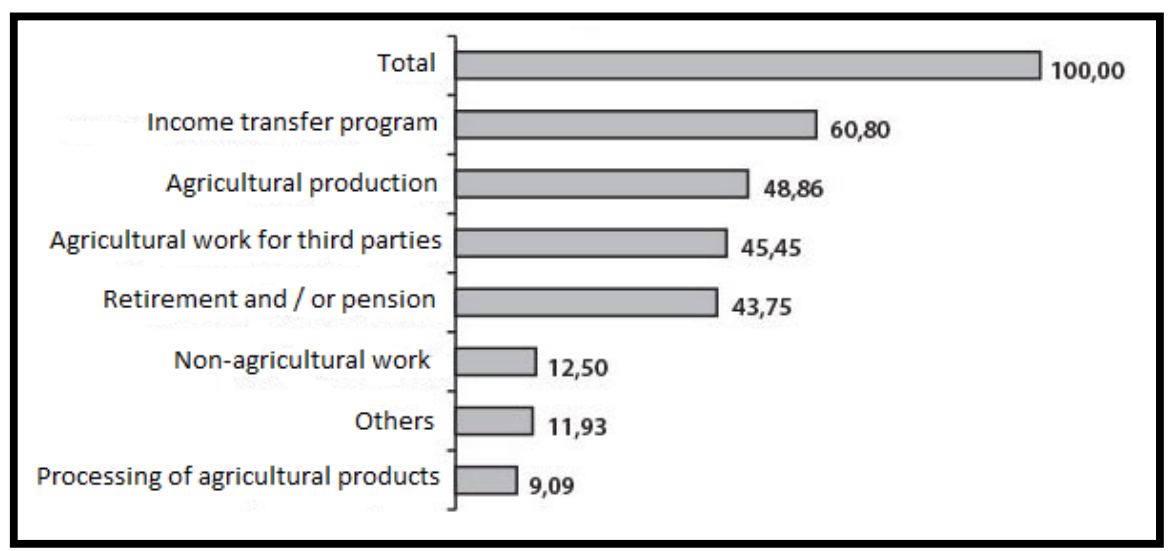

Fig. 5. Jequitinhonha Valley: the main sources of cash income of rural families surveyed in selected municipalities, 2010 (Source: [21]).

Thus, the definition of the study area obeyed to technical criteria of the proposed study and availability of database; therefore, municipalities should have availability or possibility of availability of solar radiation and wind speed, as well as having INMET (National Meteorological Institute) station, in addition to prioritizing a greater diversity of municipalities located near the Jequitinhonha Valley. According to the aforementioned premises, the study cities were chosen based on the solarimetric and wind atlases of Minas Gerais and Brazil [12], [16], [3], [4], which mapped the territory of study (Minas Gerais and Brazil), identifying areas of greater solar and wind power generation potential individually. The following municipalities were defined: Almenara, Diamantina, Espinosa, Governador Valadares, Montes Claros, Pirapora, Salinas, Três Marias and Uberlândia (Fig. 6). 
The nine municipalities studied have a high electrical coverage, with the lowest coverage is found in Almenara, 96\% coverage [6]. The project is justified in these municipalities by the availability of resources, in addition, some of these municipalities, such as Almenara, are in a situation of shortage. This system would then bring savings with energy costs, bringing an important social part to work.

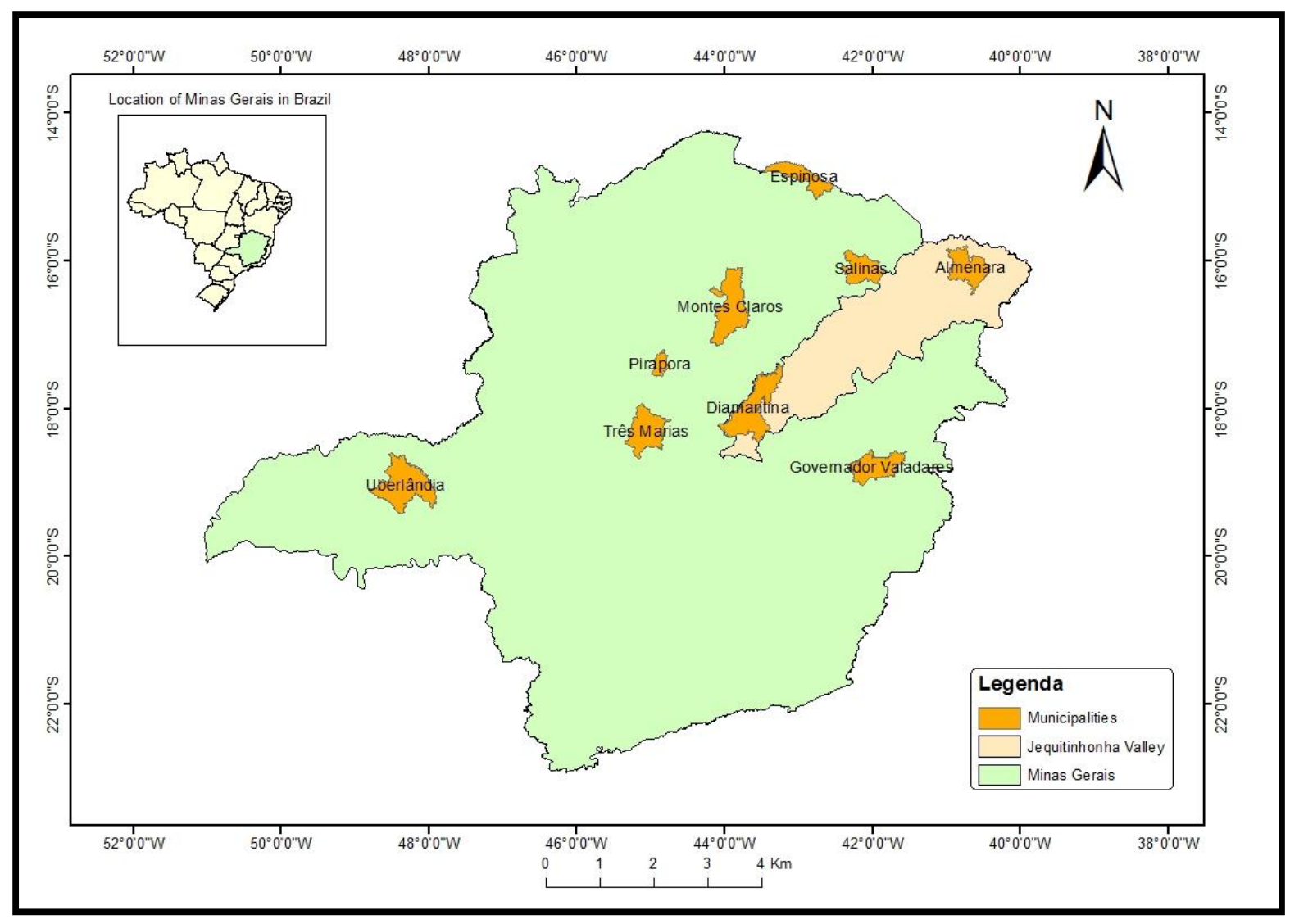

Fig. 6 Jequitinhonha Valley and potential municipalities.

\subsection{Energy Consumption}

Knowledge about municipal energy consumption is of paramount importance for the success of this work. In order to obtain municipal consumption data from the study area, data was collected on the average residential use in Minas Gerais [22] and the residential coverage of each municipality [6].

\subsection{Hybrid Potential}

The evaluation of the hybrid potential occurred in two ways: bibliographic research and use of INMET (National Meteorological Institute) database.

Bibliographical researches were carried out on renewable sources of electric, solar, and wind power generation in order to understand the operation of these and their availability in the state of Minas Gerais. The main sources used were the solar and wind energy atlases of Minas Gerais and Brazil [12], [16], [3], [4], and consult experts in the energy sector [23], [24]. The investigation of potential hybrid generation centers was carried out based on the atlases previously mentioned.

In possession of the INMET database, which contains radiation and wind velocity records for nine municipalities that compose the study area (Almenara, Diamantina, Espinosa, Governador Valadares, Montes Claros Pirapora, Salinas, Três Marias, and Uberlândia), real information of the municipalities could be worked. After all adjustments were made to the data, conversions and weights, the means of radiation and velocity of the winds were taken for each of the municipalities for all months of the year, in the present study, considering a period of three years of data for each municipality . 
The solar radiation and wind velocity data for the municipalities were comparatively analyzed in Kruskal-Wallis non-parametric variance test and for Dunn's test the Dunn test was used in the BioEstat 5.3 program [25].

\subsection{System Dimensioning}

The design of a hybrid system depends on the local electricity consumption, the efficiency of the equipment, and the availability of natural resources. The participation of the energy sources to be used is defined by the one that demonstrates lower cost while supplying the demand [26]. This participation follows the premise that if the fraction of the load to be supplied by the photovoltaic matrix is ' $\mathrm{f}$ ', then ( $\mathrm{f}-1$ ) of the demand must be covered by the wind generator, which together result in $100 \%$ hybrid system.

For the purposes of system design, as well as for cost basis, generic models of photovoltaic and wind power systems were used according to [27], the specifications of these can be seen in Tables 1-4 (Table 1-4). The amount of equipment, and consequently the final value, varies among municipalities, since the needs and environmental characteristics differ between them, and different sizing is required for each location.

Table 1. PV module.

(Source: adapted [27], 2015.)

\begin{tabular}{ll}
\hline Description & Specification \\
\hline Material & Polycrystalline silicon \\
Nominal power & $1 \mathrm{~kW}$ \\
Nominal load voltage & $20.5 \mathrm{~V}$ \\
Short circuit current & $2.96 \mathrm{~A}$ \\
Current at maximum power point & $2.74 \mathrm{~A}$ \\
Nominal efficiency & $15 \%$ \\
Capital cost & $1,500 \mathrm{R} \$$ \\
Lifetime & 25 years \\
\hline
\end{tabular}

Table 2. Wind Generator.

\begin{tabular}{ll}
\hline Description & Specification \\
\hline Rotor diameter & $3 \mathrm{~m}$ \\
Blades & 3 -carbon fiber composite \\
Start-up wind speed & $3 \mathrm{~m} / \mathrm{s}$ \\
Capacity & $10 \mathrm{~kW}$ \\
Over speed protection & Electronic torque control \\
Capital cost & $1.000 \mathrm{R} \$$ \\
Lifetime & 20 years \\
\hline
\end{tabular}

(Source: adapted [27], 2015.)

Table 3. Battery bank.

(Source: adapted [27], 2015.)

\begin{tabular}{ll}
\hline Description & Specification \\
\hline Nominal voltage & $12 \mathrm{~V}$ \\
Nominal capacity & $83 \mathrm{Ah}$ \\
Nominal energy capacity of & $1 \mathrm{KWh}$ \\
each battery ( $\left.{ }^{*} \mathrm{Ah} / 1000\right)$ & \\
Capital cost & $70 \mathrm{R} \$$ \\
life expectancy & 10 years \\
\hline
\end{tabular}


Table 4. Inverter.

\begin{tabular}{ll}
\hline Description & Specification \\
\hline $\mathrm{P}_{\text {nominal }}$ & $2000 \mathrm{Wp}$ \\
Peak inverter efficiency & $94-94.4 \%$ \\
$V_{A C} \%$ & $198-251 \mathrm{~V}$ \\
Efficiency & $94-94.4 \%$ \\
Capital cost & $800 \mathrm{R} \$$ \\
Lifetime & 20 years \\
\hline
\end{tabular}

(Source: adapted [27], 2015.)

The global formula for estimating the electricity generated in a photovoltaic system is Eq. (2) [28]:

$$
E=A * r * H * P R
$$

where $E=$ Energy $(\mathrm{kWh}) ; A=$ Total panel area $\left(\mathrm{m}^{2}\right) ; r=$ Efficiency of the solar panel $(\%) ; H=$ Average solar radiation; $P R=$ Performance ratio, loss coefficient (range between 0.5 and 0.9 , standard value $=0.75$ ). In order to calculate the photovoltaic electric generation the photovoltaic-software calculator was used, which follows the equation quoted above Eq. (2)

Regarding the electrical production of wind power sources, it follows Eq. (1) as shown in section 1.2.1.

$$
P(\text { Watts })=\frac{1}{2} \rho A_{r} V^{3} C_{p} \eta
$$

The wind presents different speeds in its vertical profile. In order to use wind power for electric generation, a typical height of the wind turbines is $30 \mathrm{~m}$, but the INMET stations measure the velocity of the winds at $10 \mathrm{~m}$ from the ground, requiring the application of the Logarithmic Law of the Winds [29]). The equation that governs this law is that which follows Eq. (3).

$$
V=V_{\text {ref }} \ln \left(\frac{Z}{Z_{0}}\right) / \ln \left(\frac{Z_{r e f}}{Z_{0}}\right)
$$

where $V=$ wind velocity at $z$ height above ground level; $V_{r e f}=$ Reference speed, ie a wind speed already known at a height $Z_{\text {ref }}$; $\ln =$ Natural logarithm function; $Z=$ Height above ground level for desired speed v; $Z_{0}=$ Roughness length in the current wind direction; $Z_{r e f}=$ Reference height, i.e. the height at which we know the exact wind speed.

The wind potential also depends on the roughness of the soil. For the study cities, $1 \mathrm{~m}$ roughness is assumed, which considers the typical relief of Minas Gerais demonstrated in the Atlas of Brazilian wind potential [3].

\section{Results and Discussions}

\subsection{Energy Consumption}

The consumption of electric energy in Minas Gerais in 2014 was 10,698 GWh to 6,884,946 households [22], thus the average residential consumption of the state was $1.55 \mathrm{MWh} /$ year or $129 \mathrm{kWh} / \mathrm{month}$. The residential electrical consumption of the studied municipalities is shown in Table 5. 
Table 5. Energy consumption of the studied municipality.

\begin{tabular}{lll}
\hline Municipality & $\mathbf{N}^{\mathbf{o}}$ residencies & $\begin{array}{l}\text { Municipality consumption } \\
\text { (GWh/year) }\end{array}$ \\
\hline Almenara & 10,168 & 1.31 \\
Diamantina & 9,322 & 1.20 \\
Espinosa & 7,109 & 0.92 \\
Governador Valadares & 76,615 & 9.90 \\
Montes Claros & 99,667 & 12.87 \\
Pirapora & 15,006 & 1.94 \\
Salinas & 10,156 & 1.31 \\
Três Marias & 8,176 & 1.06 \\
Uberlândia & 191,766 & 24.77 \\
\hline
\end{tabular}

(Source: [22] and [6] adapted.)

Uberlândia, since it is the most populous municipality of the study, is also the one that presents greater consumption of the residential class.

\subsection{Hybrid Potential}

The municipality was considered as viable for implantation of photovoltaic system when the average radiation index is $5.5 \mathrm{kWh} / \mathrm{m}^{2}$.day [12]. For the radiation in $\mathrm{kWh} / \mathrm{m}^{2}$.day of the municipalities, according to the analyzes to the INMET database [30] were the following: Almenara 5,5; Diamantina 5.3; Espinosa 6.2; Governador Valadares 5,0; Montes Claros 5,7; Pirapora 5.9; Salinas 5,9; Três Marias 5,7; Uberlândia 5,4 (Fig. 7). The municipalities that are not able to receive photovoltaic generation fields are only Diamantina, Governador Valadares and Uberlândia. The variation of daytime radiation (insolation) is also an important factor being represented in (Fig. 8), indicating that the values are increasing between $10 \mathrm{~h}$ to $15 \mathrm{~h}$, remaining constant until 16h when it decreases again. The total insolation data also indicated significant results $(\mathrm{H}=$ 31.0098; $\mathrm{p}=0.0001)$, and comparative analyzes showed that Espinosa was significantly $(\mathrm{p}<0.05)$ higher than Diamantina, Governador Valadares and Três Marias.

As for the wind sector, the turbines are activated when the winds reach a speed of $3 \mathrm{~m} / \mathrm{s}$. From the municipalities studied, some do not present feasibility for wind energy exploration even after the application of the Logarithmic Law of the Winds (Fig. 9). It is worth to mention that these values are $30 \mathrm{~m}$ from the ground where in reality, this would be different at higher altitudes, making the project economically unfeasible. Diamantina, Espinosa and Três Marias have satisfactory wind levels throughout the year; therefore, these municipalities would be able to receive wind farms, making the hybrid system possible. These data were corroborated by the variance test that indicated a significant difference of these municipalities in relation to the others that were analyzed $(\mathrm{H}=72.0573$; $\mathrm{p}<0.0001)$. Of the municipalities eligible for the hybrid system, only Espinosa has no wind availability during the 24 hours of the day (Fig. 10). 


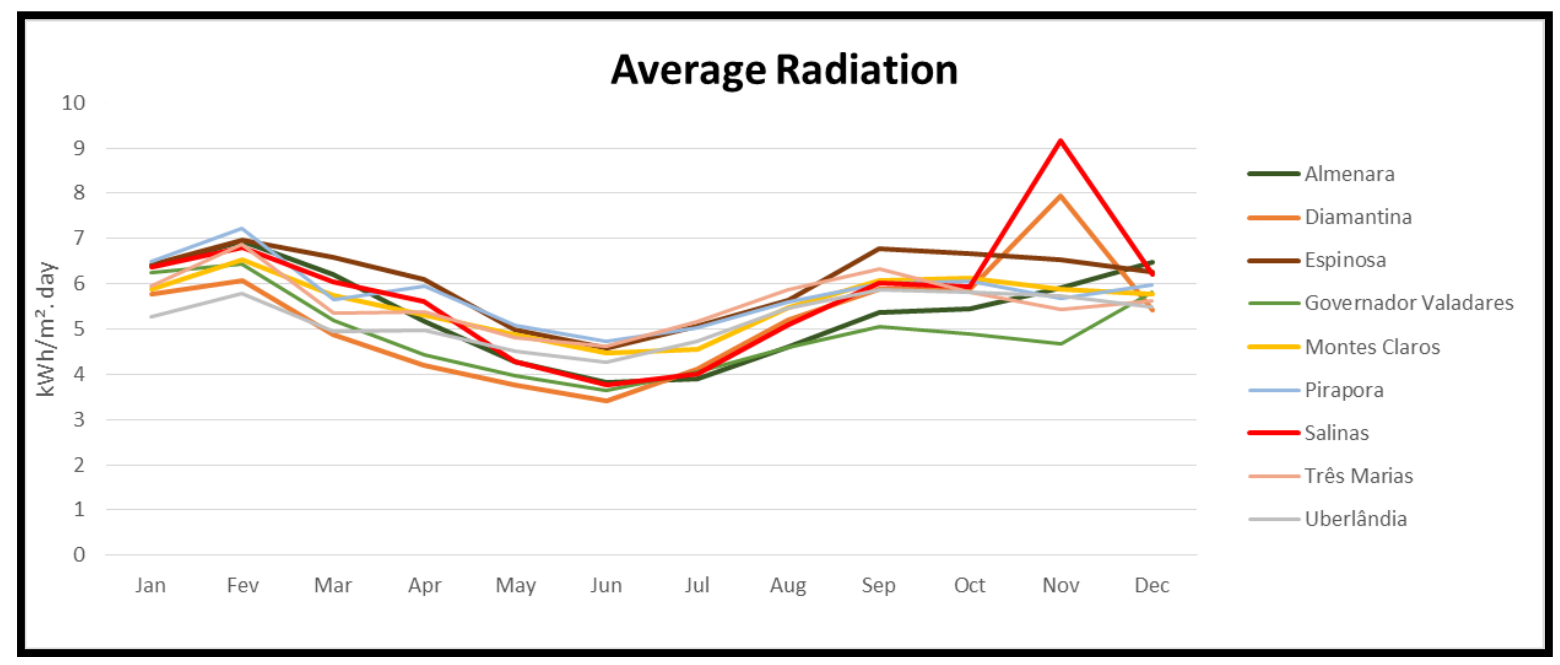

Fig. 7. Average Radiation for studied municipalities.

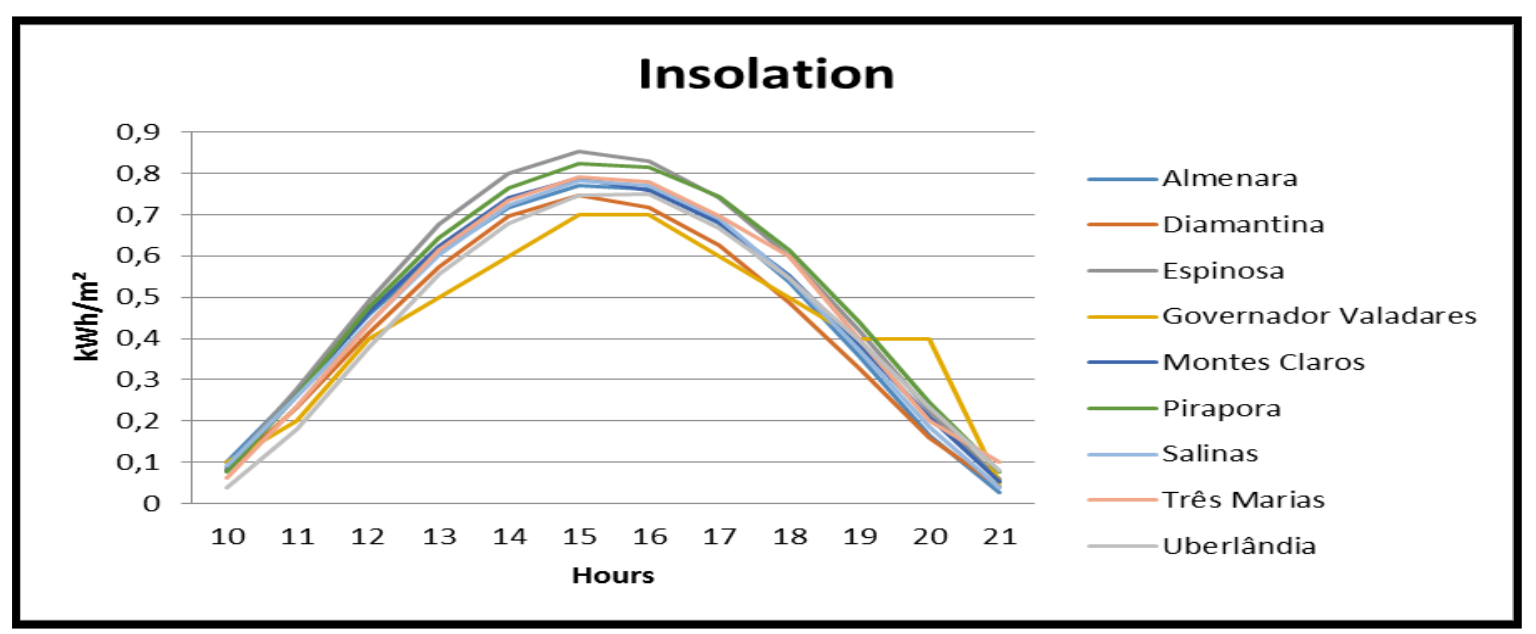

Fig. 8. Average insolation for studied municipalities.

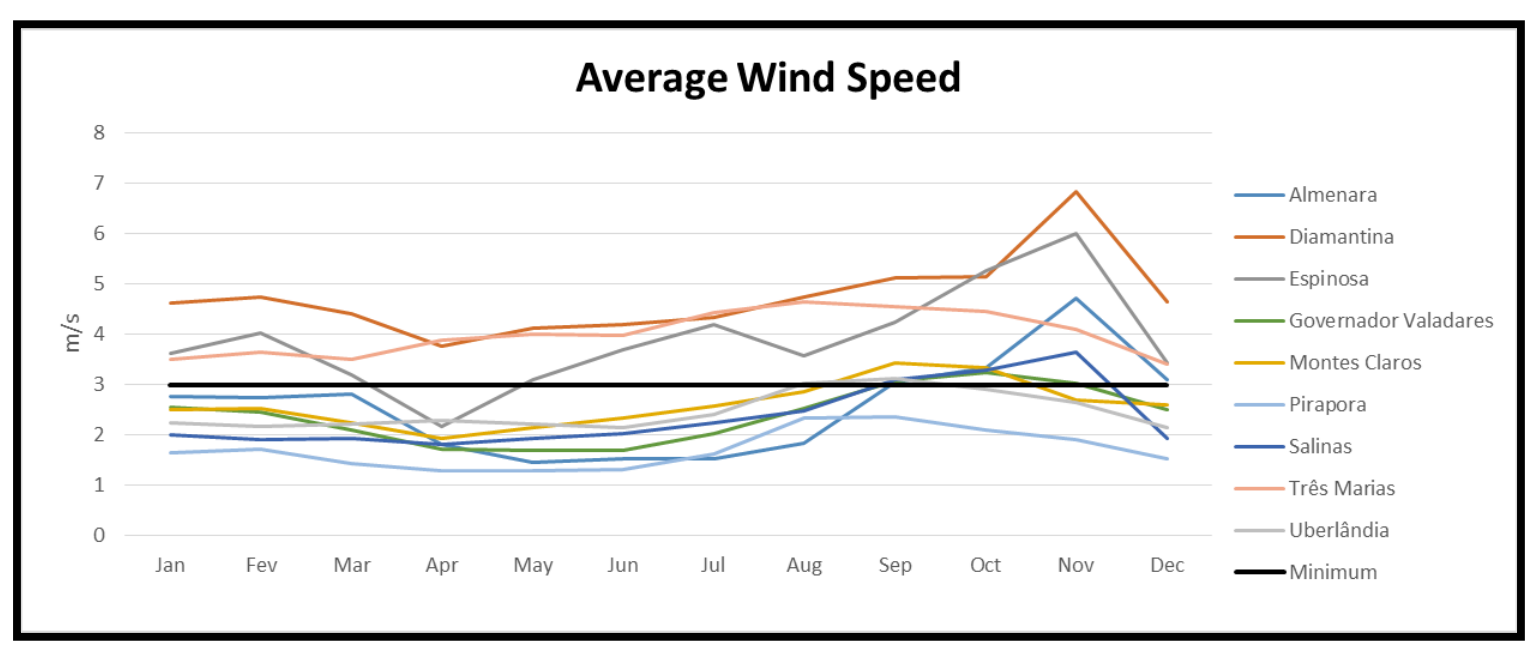

Fig. 9. Average wind speed for studied municipalities. 


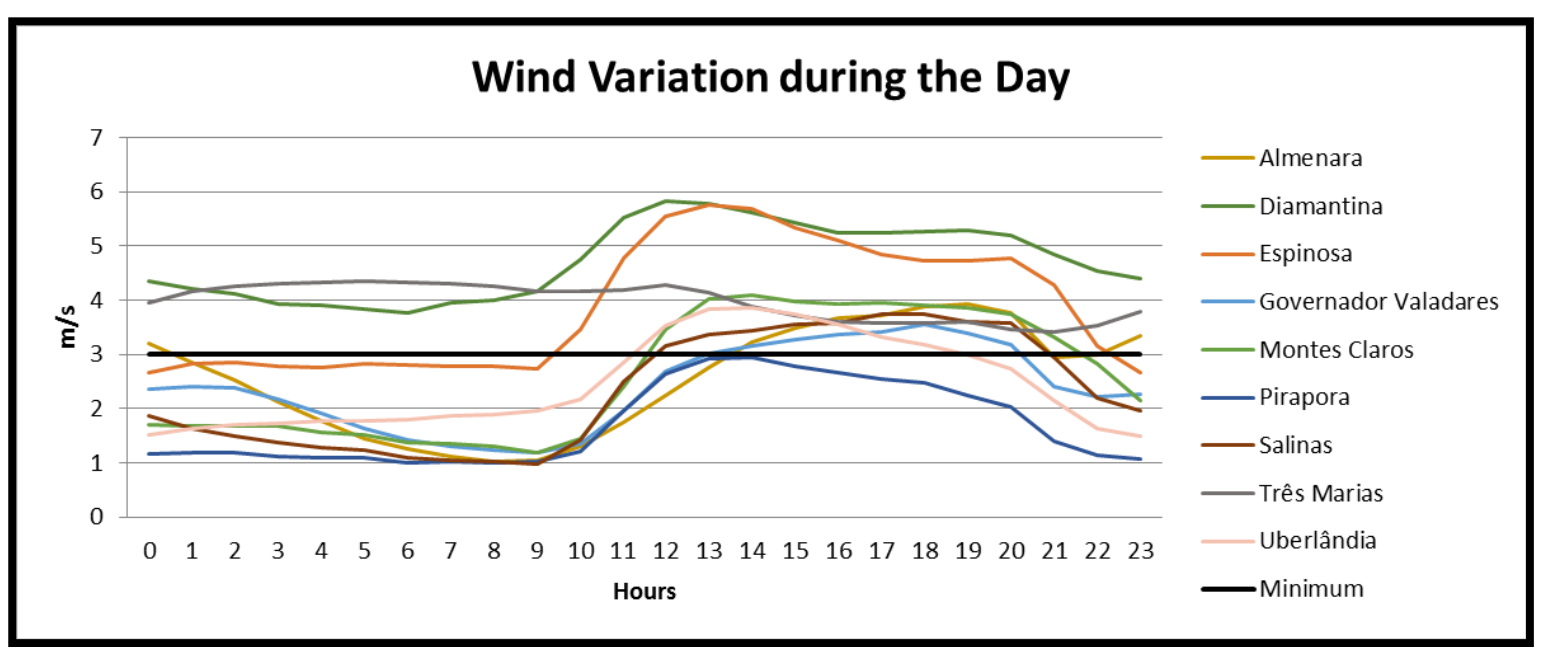

Fig. 10. Average wind behavior during the day for studied municipalities.

\subsection{System Dimensioning}

The sizing of each municipality follows the principle of use of renewable sources in the generation of 100\% of municipal consumption in the residential category. Considering the use of the two renewable energy sources, the load is divided into two parts; the fraction to be supplied by the photovoltaic matrix ' $\mathrm{f}$ ', and ( $\mathrm{f}$ 1) the demand that must be covered by the wind system. Since each municipality has a different demand, solar radiation and different wind speeds, the dimensioning and the ' $f$ ' fraction also differ.

Once the municipalities Espinosa and Três Marias demonstrated hybrid potential (solar and wind), the portion ( $\mathrm{f}-1$ ) is different from zero. Diamantina in turn considered the photovoltaic portion as zero, since it did not present the minimum value of daily radiation average, but presents high degrees of wind speed. The existence of the wind field in the municipality of Gouveia, near Diamantina, corroborates the data found in this document [31]. Governador Valadares and Uberlândia did not present feasibility of implantation of any of the systems in the standards of the present study, for all others, sizing was done considering only the photovoltaic system, since the wind velocities in them do not make feasible projects in this sector.

Table 6. shows the amount of photovoltaic panels and aerogenerators needed for each municipality in the specifications mentioned in section 2.2.3 (Table 6). The estimated cost also considered the values of batteries and inverters, which were specified in the same section.

Table 6. Energy consumption of the studied municipalities.

\begin{tabular}{lllll}
\hline Municipality & $\begin{array}{l}\text { Consumption } \\
(\mathbf{G W h})\end{array}$ & $\mathbf{N}^{\circ}$ Panels & $\begin{array}{l}\mathbf{N}^{\circ} \text { de Wind } \\
\text { generators }\end{array}$ & Estimated Cost (R\$) \\
\hline Almenara & 1.31 & 6,000 & 0 & $6,581,538.46$ \\
Diamantina & 1.20 & 0 & 120 & $507,600.00$ \\
Espinosa & 0.92 & 25 & 90 & $408,123.08$ \\
Governador Valadares & 9.90 & 0 & 0 & - \\
Montes Claros & 12.87 & 55,000 & 0 & $60,330,769.23$ \\
Pirapora & 1.94 & 8,000 & 0 & $8,775,384.62$ \\
Salinas & 1.31 & 5,500 & 0 & $6,033,076.92$ \\
Três Marias & 1.06 & 40 & 105 & $488,026.92$ \\
Uberlândia & 24.77 & 0 & 0 & - \\
\hline
\end{tabular}

As shown in Table 6, hybrid systems, when technically feasible, should be prioritized, since they present lower costs. This is because a single wind turbine, in the characteristics mentioned in the article, has power transformation of $10 \mathrm{~kW}$ in counterpoint to the $1 \mathrm{~kW}$ of the solar panel, reflecting in the final cost of the project. However, a hybrid system also counts on the solar resource, which offers greater security to the 
system considering the seasonality of the winds. The wind resource is the second resource that presents the best initial cost, losing only to hydroelectric power stations [32], which proves the data obtained in this study.

\subsection{Environmental Perspective}

Wind and solar energy have zero emission of pollutants during the operation phase, but like any other energy source, they have negative environmental impacts to be considered and mitigated, although much smaller compared to traditional sources [33].

One of the main negative environmental impacts of a wind farm is the collision of birds against the structure. While bird deaths are severe, other anthropological activities have a major influence on this number. Considering the United States, collisions with buildings kill 97 - 976 million birds annually; collisions with power lines kill at least 130 million birds, perhaps more than 1 billion; collisions with communications towers kills between 4 and 5 million based on "conservative estimates", but could be as high as 50 million. Cars can kill birds on the order of 80 million per year; toxic chemicals, including pesticides, kill more than 72 million birds each year. Domestic cats are estimated to kill hundreds of millions of songbirds and other species each year; and collisions with wind turbines killed an estimated 20,000 to 37,000 birds per year [34]. Thus, the death of birds by collision in the turbines represents less than $0.003 \%$. In order to minimize this impact, the turbines have become larger, which requires a smaller rotation, facilitating their visualization by the birds [3]. Other impacts that can be cited are noise and visual pollution.

Regarding the impacts on solar energy, the raw material for the production of photovoltaic panels is silicon. Their extraction then characterizes the main form of impact in the environment, since the material mining continues in a traditional way. Although this fact is a negative aspect, it presents competitive power to the Brazilian market, since the country has large reserves of quality quartz that can generate silicon with high purity, cells and solar modules [10]. Minas Gerais is the second state with the largest reserve of quartz in the country, only behind Pará [35]. Another impact of the photovoltaic system is related to the possibility of thermal imbalances occurring in the area, which may affect some species [36]. In addition, there is land use conflict, since large areas are required for a large-scale solar and wind power generation system [37].

\subsection{Social Perspective}

Projects in renewable energies offer social benefits. In general, there are two reasons why these projects are more attractive than traditional energy technologies under an employment perspective: (1) they require more labor, so they create more jobs per invested currency, and (2) jobs tend to be created in rural areas, this being a struggle against rural exodus [38], [39].

In addition to job benefits, non-release of pollutants provides health and safety benefits for the population. According to the [40], life cycle greenhouse gas emissions associated with renewable energy including manufacturing, installation, operation and maintenance and dismantling - are minimal. Pollution of air and water emitted by coal and natural gas plants, for example, is linked to respiratory problems, neurological damage, heart attacks and cancer [39]. Substituting fossil fuels for renewable energy can reduce premature mortality and generally reduce health costs [41].

In addition, wind and solar energy systems do not essentially require water resources to operate and therefore do not pollute or conflict with water supply, i.e. do not compete with agriculture, potable water systems or other major needs [39].

\section{Final Considerations}

The growing environmental concern leads to the search for more sustainable development models, the presented project constitutes an energetic alternative that follows the requirements of sustainability, that is, it is economically feasible, it offers social benefits and its negative environmental impacts are much smaller when compared to traditional energy sources.

The analysis conducted in the present study demonstrated that the municipalities of Minas Gerais are able to receive energy production fields from renewable sources (solar and wind), either in a hybrid way or from a single source. In general, the country has a large availability of resources being at levels that exceed countries in Europe and the United States. These technologies are widespread, requiring public policies and 
government programs to accelerate the development of these technologies on the country. In this context it is possible to see the contradictory scenario of the country, where projects of nuclear power plants are encouraged to the detriment of renewable sources, such as solar, wind.

Angra I and II nuclear plants, with a combined capacity of about $2000 \mathrm{MW}$, received an investment of $\mathrm{R} \$ 6.576$ billion [42]. Nuclear plants interfere with the biosphere, even if their production process does not emit pollutants, they can pose risks to public safety. Nuclear power produces a hazardous material with a high potential for harm to the population and the environment, being vulnerable to natural climatic phenomena and geological events, such as the example at the Fukushima I - Japan Nuclear Power Plant in March 2011, where 22,000 people were killed or missing. A photovoltaic field of this proportion (2000 MW) would cost about $\mathrm{R} \$ 8$ billion, as shown in this project (see Table 6, Pirapora), the value is close to what was spent in the nuclear power plants, and it is an cleaner option, free of risk to the population.

These forms of energy are still not widely used because hydroelectric plants continue to be more economically viable [23], [24], but it is worth mentioning that the models proposed in the study also have the objective of diversifying the national energy matrix, Brazilian market and protecting it in times of water scarcity.

Finally, the study confirms the feasibility and benefits of the implementation of renewable energy systems in the state of Minas Gerais with analysis of databases and bibliographic research. These projects may be the answer to the energy needs of the Jequitinhonha Valley and other locations in Brazil.

\section{Acknowledgments}

Life is easier with the support of people we value, so I would like to thank the G'd and my family for all the support. Thanks also to my advisor, Júnio Damasceno, for all the help during this study, to whom I owe the success of this work. I would also like to thank UNIBH, the university center that offered my training, CEMIG staff who kindly granted interviews and the "Eolar" group at UNIBH who volunteered to help. In addition, I thank everyone who has helped in any way to the success of this work.

\section{References}

[1] S. Baghel, R. Jha, and N. Jindal, "Material selection for dye sensitized solar cells using multiple attribute decision making approach," Joumal of Renewable Energy, vol. 7, p. 2014. doi:10.1155/2014/506216

[2] S. Kumar and V. K. Garg, "A hybrid model of solar-wind power generation system," International Journal of Advanced Research in Electrical, Electronics and Instrumentation Engineering, vol. 2, no. 8, pp. 41074116, 2013.

[3] CRESESB, Reference Center for Solar and Wind Energy. (2001). Atlas of Brazilian Wind Potential. rasília, 2001. [Online]. Available: https://goo.gl/7q2iSh [Accessed: 01 Apr. 2016].

[4] E. B. Pereira, F. R. Martins, S. L. Abreu, and R. Ruther, Braqiilian Atlas of Solar Energy, 1st ed. São José dos Campos, 2006. Available: https://goo.gl/vhlZLw [Accessed: 01 Apr. 2016].

[5] European Database for Daylight and Solar Radiation. (2005). Available: https://goo.gl/9DCsqr [Accessed: 01 Apr. 2016].

[6] IBGE, Brazilian Institute of Geography and Statistics. Censos, 2010.

[7] IEA, International Energy Agency, "Solar energy perspectives," in Renewable Energy Technologies, 2011, ch. 2 .

[8] O. C. Chaim, "Análise de custo de fontes alternativas de energia," Doctoral dissertaion, Universidade De São Paulo, São Carlos, 2011. Available: https://goo.gl/tgWPfk [Accessed: 20 Mar. 2016].

[9] S. G. O. Adejumobi, F. G. Akinboro, and M. B. Olajide, "Hybrid solar and wind power: An essential for information communication technology infrastructure and people in rural communities," International Journal of Research and Reviews in Applied Sciences, vol. 9, no. 1, pp. 130-138, 2011.

[10] EPE Empresa de Pesquisa Energética, "Análise da Inserção da Geração Solar na Matriz Elétrica Brasileira," Nota técnica, 2012. Available: https://goo.gl/ofcaFm [Accessed: 03 Mar. 2016].

[11] R. Maouedj, A. Mammeri, M. D. Draou, and B. Benyoucef, "Performance evaluation of hybrid photovoltaic-wind power systems," Energy Procedia, vol. 50, pp. 797-807, 2014. Available: https://goo.gl/0KbqZk [Accessed: 21 Mar. 2016].

[12] CEMIG, Energetic Company of Minas Gerais, Solarimetric Atlas of Minas Gerais. 2012. 
[13] ANEEL, Agência Nacional de Energia Elétrica, Resolução Normativa n 481. 2012.

[14] BRASIL, Plano Brasil Maior. 2011.

[15] H. T. Ferreira, Energia Eólica: Barreiras a sua Participação no Setor Elétrico Brasileiro. São Paulo, 2008. Available: https://goo.gl/qmXuGp [Accessed: 15 Mar. 2016].

[16] O. A. C. do Amarante, F. J. L. da Silva, and P. E. P. de Andrade, Wind Atlas: Minas Gerais. 2010.

[17] WWEA, World Wind Energy Association. (2015). Worldwide wind market booming like never before: Wind capacity over 392 gigawatt. [Online]. Available: https://goo.gl/bEOCao [Accessed: 03 May 2015].

[18] D. Ludwig, "Wind-solar hybrid plants up to twice as efficient," in PV Magazine: Photovoltaic Market \& Technology. 2013. Available: https://goo.gl/vSL4mZ [Accessed: 27 Apr. 2016].

[19] T. Tyler. (2013). Solar-Wind Hybrid Power Plants Approximately Twice as Efficient. [Online]. Available: https://goo.gl/65S8d [Accessed: 01 May 2016].

[20] A. Kaabech, M. Belhamel, and R. Ibtiouen, "Optimal sizing method for stand-alone hybrid PV/wind power generation system," in Proc. Revue des Energies Renowvelables SMEE'10 Bou Ismail Tipaza, 2010, pp. 205-213. Available: https://goo.gl/M8gqw0 [Accessed: 01 Jun. 2016].

[21] E. M. Ribeiro, E. B. Ayres, F. M. Galizoni, A. F. Almeida, and V. G. Pereira, "Programas sociais, mudanças e condições de vida na agricultura familiar do Vale do Jequitinhonha Mineiro," Revista de Economia e Sociologia Rural, vol. 52, no. 2, pp. 365-386, 2014.

[22] EPE, Empresa de Pesquisa Energética, “Anuário Estatístico de Energia Elétrica 2015,” 2015.

[23] B. M. Lopes, Belo Horizonte, MG. Uni-BH student, 11 Mar. 2016, interview granted by the employee of CEMIG to Eduarda Moreira Nascimento.

[24] C. H. F. Silva, Belo Horizonte, MG. Uni-BH student, 02 Jun. 2016, interview granted by the employee of CEMIG to Eduarda Moreira Nascimento.

[25] M. Ayres, BioEstat 5.3: Aplicações Estatísticas nas Áreas das Ciências Biológicas e Médicas, $5^{\text {th }}$ ed. Belém-PA: Publicações Avulsas do Mamirauá, 2011, p. 361.

[26] E. T. Silva, E. A. Torres, and C. A. Costa, "Energização em comunidade isolada em sistema híbrido eólico e solar-fotovoltaico e irradicação da miséria: Estudo de caso de uma comunidade quilombola na Bahia," Identidade da Escola Superior de Teologia, vol. 17, no. 1, pp. 66-82, 2014. Available: https://goo.gl/hiKOiZ [Accessed: 21 Mar. 2016].

[27] A. Ataei, R. Rashidi, M. Nedaei, and E. Kurdestani, "Techno-economic viability of a hybrid wind and solar power system for electrification of a commercial building in Shiraz, Iran," Advances in Energy Research, vol. 3, no. 4, p. 13, 2015. Available: https://goo.gl/FJmWln [Accessed: 6 Oct. 2016].

[28] PHOTOVOLTAIC-SOFTWARE. (2013-2016). [Online]. Available: https://goo.gl/jZj07G [Accessed: 15 Jul. 2016].

[29] R. R. Machado. (2008). Estudo do Potencial Eólico do Pontal do Abreu - Município De Viamão - RS. [Online]. Available: https://goo.gl/RI4ZUt [Accessed: 19 Oct. 2016].

[30] INMET - National Institute of Meteorology. Database. Belo Horizonte, MG. Uni-BH student. [Online]. Available: via email by institute officials to Eduarda Moreira Nascimento [Accessed: 20 Mar. 2016].

[31] CEMIG, Energetic Company of Minas Gerais. (s.d.) Wind Energy. [Online]. Available: https://goo.gl/kmV1Tl [Accessed: 10 Nov. 2016].

[32] AEB, Associação Brasileira de Energia Eólica. (2015). Energia eólica: um potencial cada vez mais explorado. [Online]. Available: https://goo.gl/A5ktcx [Accessed: 08 Nov. 2016.]

[33] S. Jaber, "Environmental impacts of wind energy," Journal of Clean Energy Technologies, vol. 1, no. 3, 2013. Available: https://goo.gl/oyfMs8 [Accessed: 13 Apr. 2016].

[34] National Research Council, "Ecological effects of wind-energy development," in Environmental Impacts of Wind-Energy Projects, 2007, pp. 48-90. Available: https://goo.gl/Nm8fYA [Accessed: 03 Oct. 2016].

[35] MME, MINISTÉRIO DE MINAS E ENERGIA. (2009). Desenvolvimento de Estudos para Elaboração do Plano Duodecenal (2010 - 2030) de Geologia, Mineração e Transformação Mineral. [Online]. Available: https://goo.gl/Nm8fYA [Accessed: 4 Oct. 2016].

[36] H. Gunerhan, A. Hepsasli, and U. Giresunlu, "Environmental impacts from the solar energy system," Energy Sources, Part A Recovery Utilization and Environmental Effects, vol. 31, no. 2, pp. 131-138, 2008.

[37] D. Turney and V. Fthenakis, "Environmental impacts from the installation and operation of largescale solar power plants," Renewable and Sustainable Energy Reviews, vol. 15, no. 6, pp. 3261-3270, 2011. Available: https://goo.gl/v3fqmt [Accessed: 05 Nov. 2016]. 
[38] EA, Energy Analyses. (2007). Renewable Energy Costs and Benefits for Society RECABS. [Online]. Available: https://goo.gl/xP2YJL [Accessed: 20 Sep. 2016].

[39] UCSUSA, Union of Concerned Scientists, (2013). Benefits of Renewable Energy Use. [Online]. Available: https://goo.gl/Uf0DDN

[40] IPCC, Intergovernmental Panel on Climate Change. (2011). IPCC Special Report on Renewable Energy Sources and Climate Change Mitigation. [Online]. Available: https://goo.gl/OQsHrO [Accessed: 27 Sep. 2016].

[41] R. Machol, "Economic value of U.S. fossil fuel electricity health impacts," Environment International, vol. 52, pp. 75-80, 2013. Available: https://goo.gl/d3ek4U [Accessed: 20 Apr. 2016].

[42] ELETRONUCLEAR. (2008). Balanço Anual (2007). [Online]. Available:

https://goo.gl/yQ3UdX [Accessed: 22 Oct. 2016]. 